\title{
The effectiveness of using blogs on improving secondary school students`creative writing skills
}

\section{The effectiveness of using blogs on improving secondary school students`creative writing skills}

\author{
By \\ Maha Abdel- Sabour El-Sawi \\ An English Language Supervisor \\ Hurghada Educational Administration
}

\begin{abstract}
Supervised by
Prof. Mohamed Abdel Wahid Ali

Dr. Haggag Mohamed Haggag

Professor of Curricula and TEFL Methodology

An Assistant professor of Curricula and TEFL

Methodology

New Valley Faculty of Education

Hurghada Faculty of Education

Assiut University

South Valley University
\end{abstract}




\section{مجلة العلوم التربوية ـ كلية التربية بالغردقة ـ جامعة جنوب الوادى}

\section{Abstract}

This study investigated the effectiveness of using a blog on improving creative writing skills of first-year secondary school students. The sample of the study consisted of (30) students at Mohamed El-Tayeb Official Language School. It utilized the one group quasi-experimental design with its pre-post testing procedures. The instruments included a creative writing skills test for secondary school students, creative writing skills checklist, a rubric for assessing the creative writing skills test and interviews for teachers and students. It was administered to measure the effectiveness of using the blogs. The study was conducted during the academic year 2019/2020. The results showed that there were statistically significant differences between the mean scores of the participants in the pre-post testing of creative writing skills favoring the post testing. The study concluded that using a blog proved to be effective and has considerable contributions in improving creative writing skills of first-year secondary school students.

\section{Key words: Blog- Creative writing- secondary stage}




\section{The effectiveness of using blogs on improving secondary school students`creative writing skills}

\section{Introduction}

Language is a valuable and unique tool that human beings possess. It is an important means that enables people to get access to the accumulated knowledge. In general, one relates to himself, others and the world through language. Today, English becomes the language of globalization, international communication, commerce and trade, as well as the media and culture. English as a language consists of four basic skills. These skills are reading, writing, listening and speaking. These skills are essentially linked to each other and each skill has its own traits.

To many authors, writing can be classified into two main kinds. Ibnian (2011) indicates that writing can be divided into two major kinds: functional and creative. As far as, functional writing refers to that kind of writing which aims at conveying a specific, direct and clear message to a specific audience. It includes different genres such as writing instruction, formal letters, notes, invitations, advertisement and reports. On the other hand, creative writing is the writing through which individuals express their feelings, opinions, reactions and ideas to the reader in a distinguished literary style. This kind of writing includes several genres such as writing short stories, poems, plays, novels, essays and diaries. Creativity is a very powerful process for people. Reddy (2002) assures that creativity is not confined to geniuses, but it exists in everyone. It is an innate ability of human beings that raises them above all the other living species. He adds that creativity is the main source of emergence and development of human culture. A creative mind is one of the most desired needs in the current time. Tamopolsky (2005) indicates that creative writing may be considered as an important part of any language program. Creative writing depends on creative mind and imagination. It is considered a unique way which can turn imagination and inspiration into visible words (Ahmed, 2011). 
Through creative writing, students can express themselves, their feelings, ideas and plans. Creative writing helps students to improve self-confidence and critical thinking (Ali, 2009). Besides, Infusing EFL (English as a Foreign Language) writing curriculum with creative writing exercises can support students creativity. Engagement in creative writing activities helps students experience higher levels of enthusiasm and motivation to improve their writing abilities because they can express themselves freely and employ their imagination (Stillar, 2013). Hennings (1997) states that writing is one of the school activities in which creativity is apparent in many different ways such as creating original ideas, choosing the right words, and playing with words. These ways urge the sense and mind. Creative writing also encourages students to use correct spelling and write well-constructed paragraphs.

El-Behery (2013) indicates that creative writing can offer avenues of expression, build writing skills, as well as much- needed confidence in the classroom. It also fosters self-esteem and builds important communication bridges between learners and teachers. He assumes that, despite its great importance, creative writing teaching and learning do not receive the sufficient interest. In most educational stages, curriculum to some extent addresses the forms of functional writing. There are rare courses for creative writing. Even if there, traditional EFL teaching methods are not adequate for developing such skills. There is a profound need for improving EFL creative writing curriculum, teaching and learning methods.

Among the modern approaches to EFL instructions is the use of Web applications such as forums, E-mail, chat, blogs and wikis. Lee (2010) indicates that these tools offer students a venue for additional interesting and engaging activities, ensure studentcenteredness and autonomy as well as interaction and connectivity, and provide opportunities to practice reading, writing, speaking and listening outside the classroom walls at their own pace, in real lifesemblance and safe environments. These applications have 


\section{The effectiveness of using blogs on improving secondary school students`creative writing skills}

functioned as collaborative writing tools which can be used to improve writing skills in general, and creative writing in particular.

Mathason (2004) defines a weblog as an online journal which can be continuously updated by its users. The attractiveness of a Weblog is enhanced by its multimodality which includes texts (profile, reflection, and feedback), colors, images, audio and video files, and hyperlinks of websites of the author's interest (Smith \& Baber, 2005; Du \& Wagner, 2007). Weblogs are organized in a reverse chronological sequence; that is, the latest published blog is in the first top entry and each published blog has a date that indicates when the blog is published. This feature allows the reader to identify which is the recent post (Zang, 2009). The posts can be edited by the author and the blogs can be archived and searchable through the database (Pinkman, 2005).

The class blog encourages learners to post messages, images and links concerning classroom discussion topics. Weblogs have been asserted to have potential values in English language education for several reasons. Weblogs provide opportunities for real communication in an authentic learning environment. The audience of the writing is not limited to the teacher but extended to classmates and other people beyond the classroom, including a global audience. Thus, weblogs raise an awareness of having an authorship and a readership. The authors publish ideas, thoughts, events and information, and readers are allowed to give feedback directly to the authors' posts (Benson \& Reyman, 2009). Blogs enhance reading comprehension, improve students' writing skills and abilities, provide an exciting and motivating learning environment in reading and writing for learners (Pinkman, 2005), and promote learner autonomy (Ward, 2004).

\subsection{Purpose of the study}

The purpose of the study is to determine the effects of using blogs on first year secondary school students creative writing skills. 


\section{مجلة العلوم التربوية ـ كلية التربية بالغردقة ـ جامعة جنوب الوادى}

\subsection{Problem of the study}

The researcher, as an EFL teacher, observed that most firstyear secondary school students' used to produce poor creative written texts. Investigating their written production showed that, they lacked the ability to be fluent in writing. They couldn`t use the figures of speech correctly. Moreover, the absence of originality and variety of sentences' length and structures were very clear in the students 'written texts. Additionally, some teachers' point of views, supervisors' opinions and specialists complains showed insufficiencies in teaching creative writing skills for first-year secondary school students`.

\subsection{Questions of the study}

1.3.1. What is the effectiveness of using a blog on improving firstyear secondary school students' creative writing skills?

-This main question could be branched into the following subquestions:

1.3.1.1. What is the effectiveness of using a blog on improving firstyear secondary school students' fluency skills?

1.3.1.2. What is the effectiveness of using a blog on improving first-year secondary school students' elaboration skills?

1.3.1.3. What is the effectiveness of using a blog on improving firstyear secondary school students` flexibility skills?

1.3.1.4. What is the effectiveness of using a blog on improving firstyear secondary school students' originality skills?

\subsection{Objective of the study}

\section{The current study aims to:}

Investigating the effectiveness of the program in improving creative writing skills of first-year secondary school students`. 


\section{The effectiveness of using blogs on improving secondary school students`creative writing skills}

\subsection{Hypotheses of the study}

The study hypothesized the following:

1.5.1. There are statistically significant differences between the mean scores of the participants in the pre-post testing of creative writing favoring the post-testing.

This main hypothesis could be branched into the following subhypotheses

1.5.1.1. There are statistically significant differences between the mean scores of the participants in the pre-post testing of fluency skills favoring the post-testing.

1.5.1.2. There are statistically significant differences between the mean scores of the participants in the pre-post testing of elaboration skills favoring the post-testing.

1.5.1.3. There are statistically significant differences between the mean scores of the participants in the pre-post testing of flexibility skills favoring the post-testing.

1.5.1.4. There are statistically significant differences between the mean scores of the participants in the pre-post testing of originality skills favoring the post-testing.

\subsection{Delimitations of the study}

The present study was delimited to:

1.6.1. A group of 30 first year Mohamed Eltayeb Official language secondary school bright students with scores more than $70 \%$ in the English language proficiency test in Hurghada

Educational Administration.

1.6.2. Deal with applying a blog.

1.6.4. Deal with some creative writing skills in the areas of fluency, elaboration, flexibility and originality. 


\section{مجلة العلوم التربوية ـ كلية التربية بالغردقة - جامعة جنوب الوادى}

\subsection{Design of the study}

The study followed the one group quasi-experimental design ( with its pre-post testing procedures).

\subsection{Instrumentation}

The researcher designed and adopted the following instruments:

1.8.1. A creative writing skills test for bright official language secondary school students (designed by the researcher)

1.8.2. An interview for piloting the research problem through identifying teachers views about the current learning and teaching methods and the extent of their sufficiency to educational outcomes (designed by the researcher).

1.8.3. An interview for piloting the research problem through identifying students' views about difficulties they face in learning creative writing skills (designed by the researcher).

1.8.4. An English language proficiency test for determining the academic level of the participants ( adopted from Haggag, M., 2013)

\section{Data Analysis}

The data analysis expresses the results regarding the study questions and hypotheses. Having applied the instruments of the study, quantitative data were collected and discussed. The researcher depended mainly on comparing mean scores of the participants using the " $t$ " value. The " $t$ " value was used because the number of the participants was 30 students and it was a suitable statistical form for the present study.

\section{Results}

The experimental design of the study depended on comparing students' scores on the test before and after using the blog. The researcher analyzed the quantitative data using the " $t$ " value formula. 


\section{The effectiveness of using blogs on improving secondary school students`creative writing skills}

\section{Testing the hypotheses}

\section{Testing the first hypotheses}

\section{Hypothesis 1:}

There are statistically significant mean differences between the mean scores of the participants in the pre-post testing of creative writing skills favoring post testing. To verify this hypothesis, the following statistical results were shown.

\section{Table 1.}

showed t-test results of pre-post testing of the students' creative writing skills.

a) T-test Results of the Students' on the Pre-post testing of creative writing skills

\begin{tabular}{|c|c|c|c|c|c|c|c|c|c|}
\hline $\begin{array}{c}\text { Variabl } \\
\text { e }\end{array}$ & $\begin{array}{l}\text { admi } \\
\text { nistr } \\
\text { ation }\end{array}$ & $\begin{array}{l}\text { No } \\
\text {. Ss }\end{array}$ & Mean & SD & DF & "t" & $\begin{array}{l}\text { Si } \\
\text { g. }\end{array}$ & $\boldsymbol{\eta}^{2}$ & $\begin{array}{l}\text { Bla } \\
\text { ke }\end{array}$ \\
\hline \multirow{2}{*}{$\begin{array}{c}\text { Creative } \\
\text { writing }\end{array}$} & Pre & \multirow{2}{*}{30} & 78.9000 & 19.78566 & \multirow{2}{*}{29} & \multirow{2}{*}{16.820} & \multirow{2}{*}{$* *$} & \multirow{2}{*}{.912} & \multirow{2}{*}{1.07} \\
\hline & Post & & 154.0690 & 13.93078 & & & & & \\
\hline
\end{tabular}

Table 1: showed that there is a statistically significant difference between the means of the participants scores on the pre-post creative writing test as the " $\mathrm{t}$ " value (16.820) was significant at 0.05 level.

These high gains of the students in the post-testing of the creative writing skills could be due to the training they had on the suggested program. The results of hypothesis one provided an answer to the first question of the study as the results indicated that the suggested program was effective in improving first-year secondary school students' creative writing skills according to Blake's modified gain ratio (1.07) and Etta's square (0.912).

In the light of the results of table 1, the first hypothesis was confirmed and figure 1 illustrates the results. 


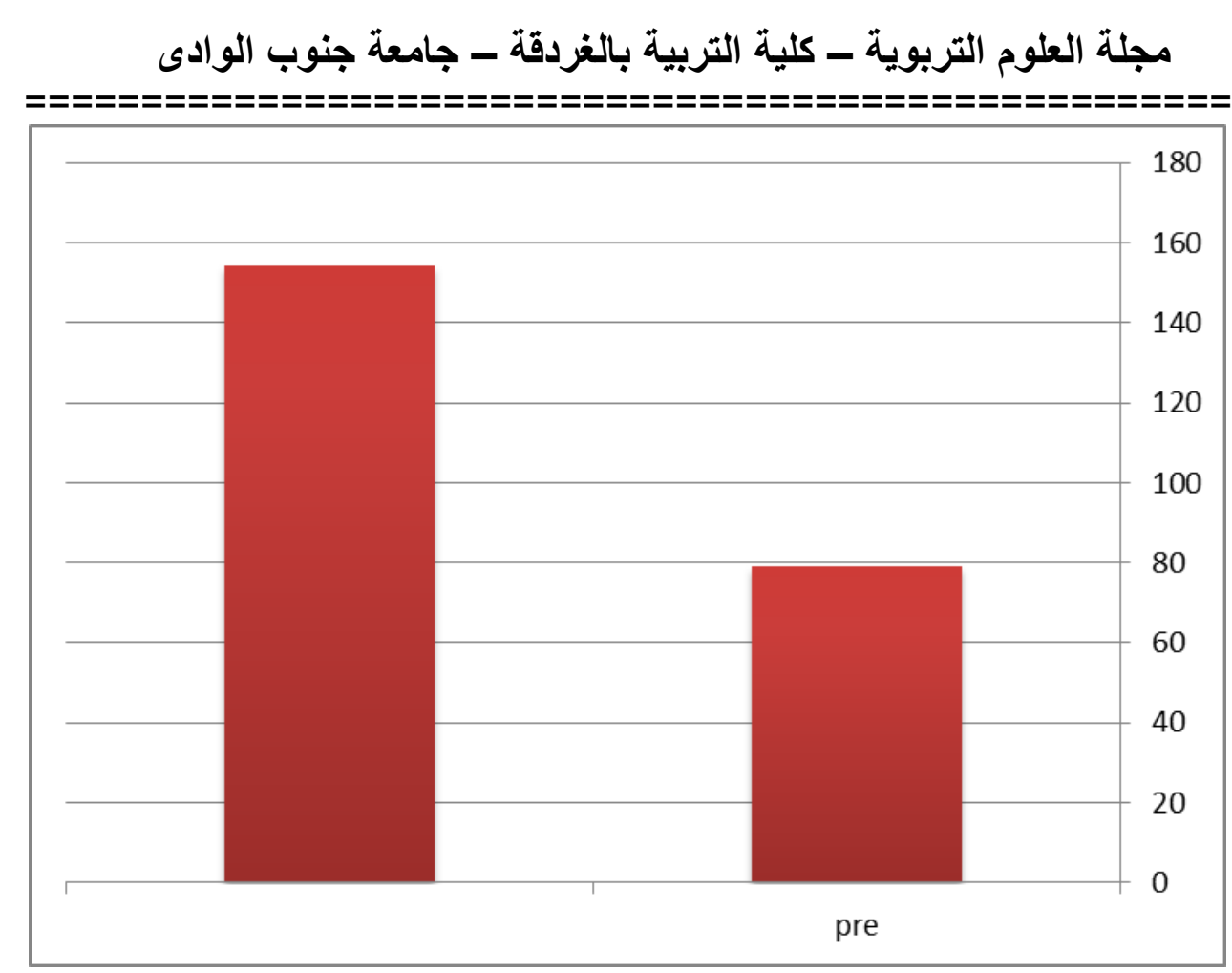

Figure 1. The Difference between pre and post testing of creative writing skills test.

The hypothesis one was branched into the following sub hypotheses:

4.2.1.1 There is a statistically significant difference between the means of scores obtained by the participants on the pre and posttests of some fluency skills (in favor of the posttest).

Table 2.

Analysis of Scores of participants in the Pre and the PostTesting of fluency Skills

\begin{tabular}{|l|c|c|c|c|c|c|}
\hline Administration & $\begin{array}{c}\text { No. of } \\
\text { Students }\end{array}$ & Means & SD & DF & $\begin{array}{c}\text { “t” } \\
\text { value }\end{array}$ & Significance \\
\hline Pre & \multirow{2}{*}{ Post } & 12.7667 & 3.04770 & \multirow{2}{*}{29} & 14.896 & $* *$ \\
\cline { 1 - 1 } & & 24.5333 & 3.07081 & & & \multirow{2}{*}{ Po } \\
\hline
\end{tabular}




\section{The effectiveness of using blogs on improving secondary school students`creative writing skills}

\section{Table 2:}

shows that the mean scores gained by the students of the group are higher on the post-testing of fluency skills (24.533) than those obtained on the pretesting (12.766). The " $\mathrm{T}$ " value is (14.896) which is significant at (0.05) level. These high gains of the students in the post-testing of fluency skills could be due to the training they had on the suggested program. The results of this hypothesis provided an answer to the first sub question of the study as the results revealed that the suggested program was effective in improving the fluency skills of participants according to Blake's modified gain ratio (1.28) and Etta's square value (0.925).

In the light of the result of table 2, the second hypothesis was confirmed and figure 2 illustrates the results.

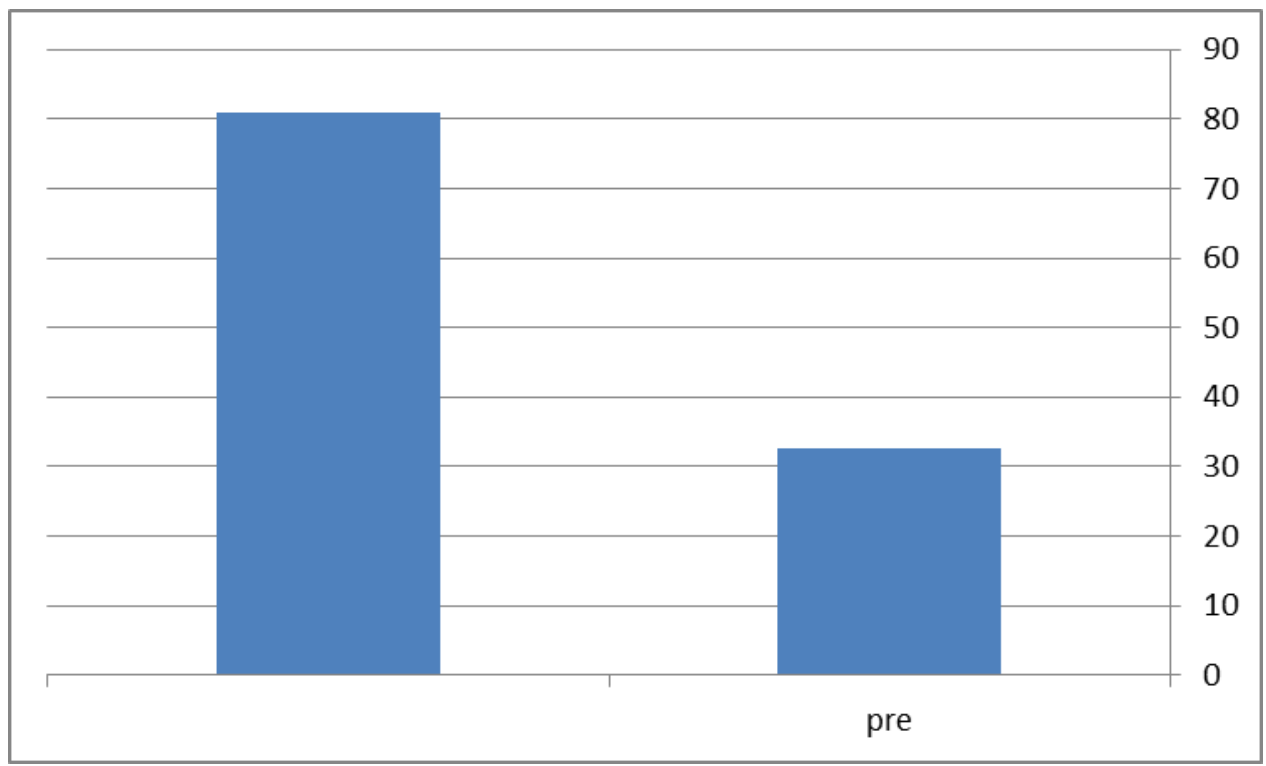

Figure 2. The difference between pre and post testing of fluency skills

4.2.1.2. There is a statistically significant difference between the mean scores of the participants on the pre-post elaboration test. 
مجلة العلوم التربوية ـ كلية التربية بالغردقة - جامعة جنوب الوادى

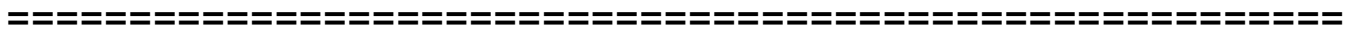

Table 3.

Analysis of Scores of participants in the Pre and the Post-Testing of Elaboration Skills

\begin{tabular}{|c|c|c|c|c|c|c|}
\hline Administration & $\begin{array}{c}\text { No. of } \\
\text { Students }\end{array}$ & Means & SD & DF & $\begin{array}{c}\text { “t” } \\
\text { Value }\end{array}$ & Significance \\
\cline { 1 - 6 } Pre & \multirow{2}{*}{30} & 21.0000 & 3.87743 & \multirow{2}{*}{29} & 11.867 & $*$ \\
\cline { 1 - 5 } Post & & 39.1333 & 7.41728 & & $* *$ \\
\hline
\end{tabular}

Table 3 shows that the mean scores gained by the students of the study are higher on the post-testing of elaboration skills (39.1333) than those obtained on the pretesting (21.0000). The "T" value is (11.867) which is significant at (0.05) level. These high gains of the students in the post-testing of elaboration skills could be due to the training they had on the suggested program. The results of this hypothesis provided an answer to the second sub question of the study as the results indicated that the suggested program was effective in improving the elaboration skills of group according to Blake's modified gain ratio (1.09) and Etta square value (0.842).

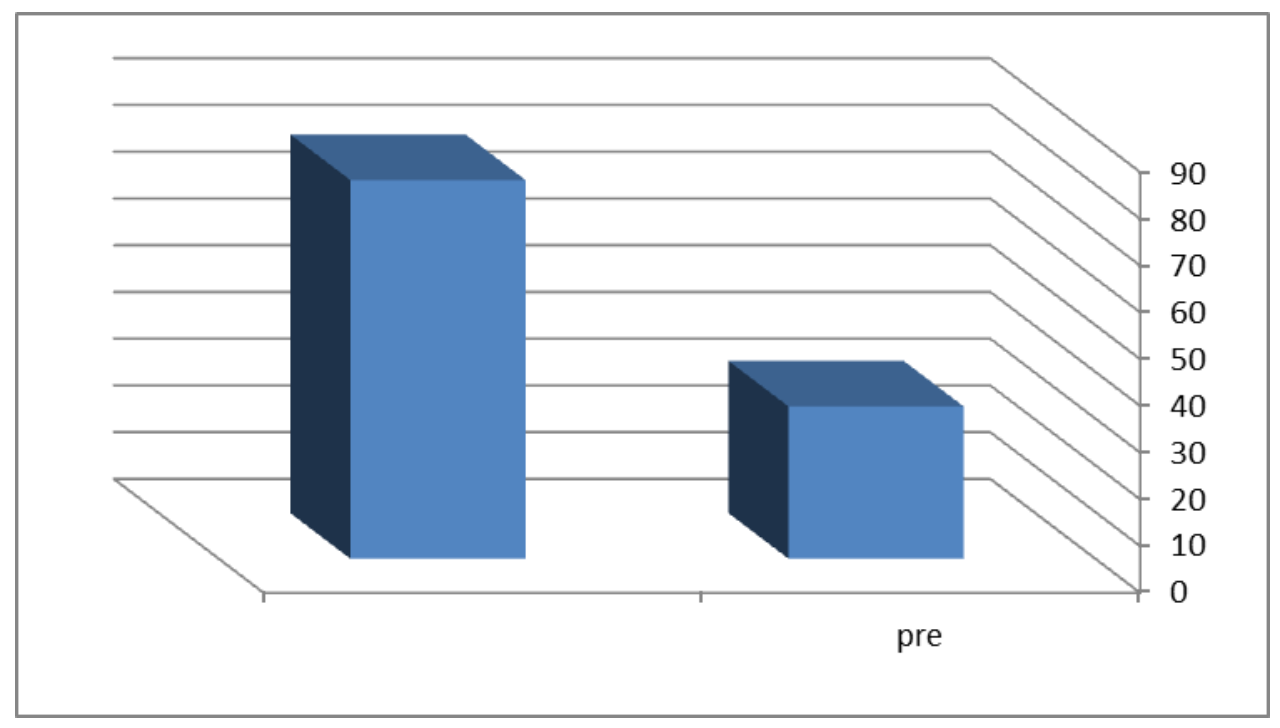

Figure 3. The Differences between pre and post testing of elaboration skills 


\section{The effectiveness of using blogs on improving secondary school students`creative writing skills}

4.2.1.3. There is a statistically significant difference between the mean scores of participants on the pre-post flexibility test.

Table 4.

Analysis of Scores of participants in the Pre and The Post-Testing of flexibility Skills

\begin{tabular}{|c|c|c|c|c|c|c|}
\hline Administration & $\begin{array}{c}\text { No of } \\
\text { Students }\end{array}$ & Mean & $\begin{array}{l}\text { Standard } \\
\text { Deviation }\end{array}$ & $\begin{array}{c}\text { Degree } \\
\text { of } \\
\text { Freedom } \\
\end{array}$ & $\begin{array}{c}\text { "tt" } \\
\text { Value }\end{array}$ & Significance \\
\hline Pre & \multirow{2}{*}{25} & 32.8333 & 5.97745 & \multirow{2}{*}{29} & \multirow{2}{*}{14.137} & \multirow{2}{*}{ * } \\
\hline Post & & 67.5000 & 12.02798 & & & \\
\hline
\end{tabular}

Table 4

shows that the mean scores gained by participants are higher on the post-testing of flexibility skills (32.8333) than those obtained on the pretesting (67.5000). " $T$ " value is (18.19) which is significant at (0.05) level. These high gains of the students in the post-testing of flexibility skills were due to the training they had on the suggested program. Results of this hypothesis provide an answer to the third sub question of the study as the results indicated that the suggested program was effective in improving the flexibility skills according to Blake's modified gain ratio (1.17) and Etta square value (0.880). 


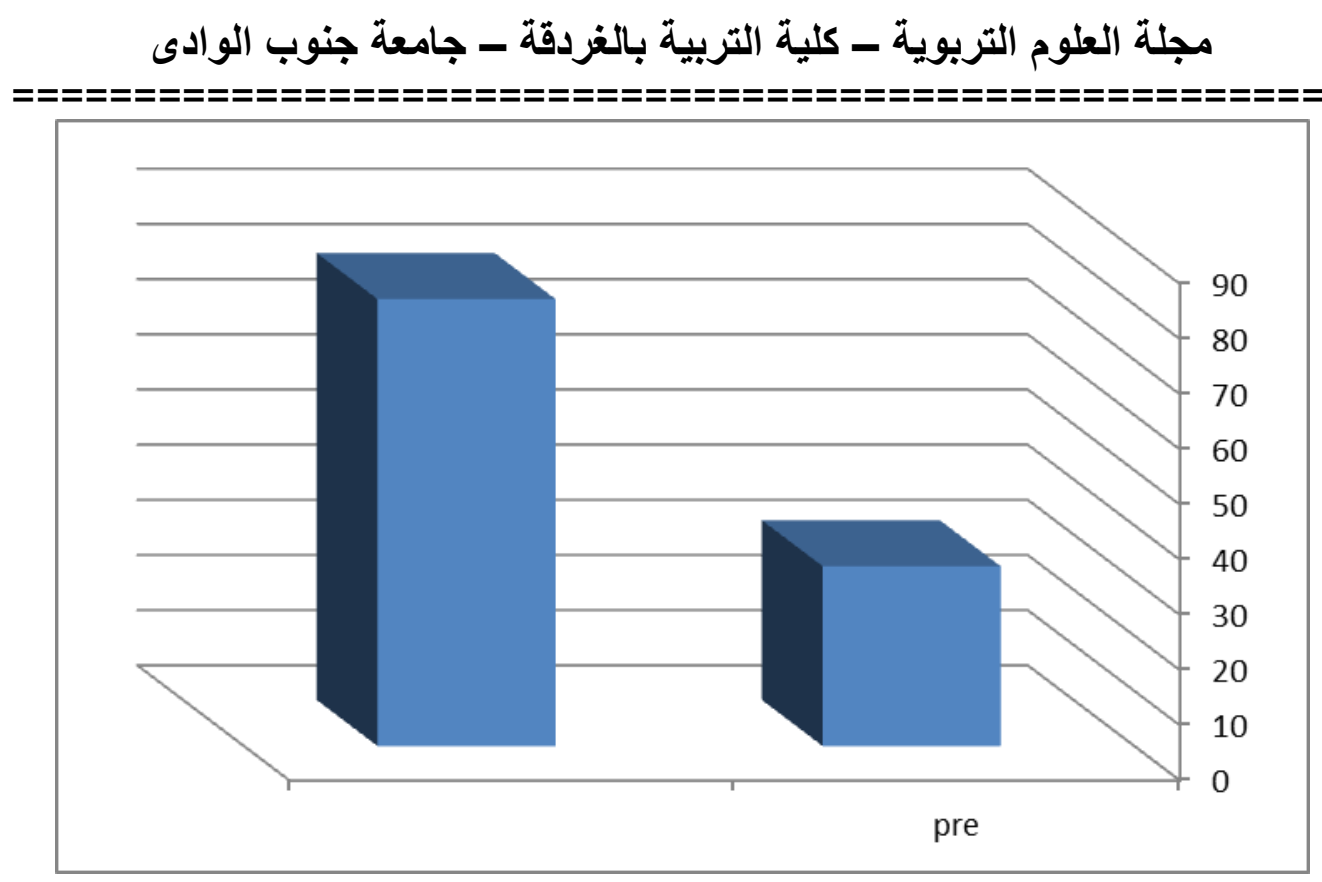

Figure 4. The Difference between pre and post testing of flexibility skills

4.2.1.4. There is a statistically significant difference between the mean scores of the participants on the pre-post originality test

Table 5.

Analysis of Scores of the participants in The Pre and The Post-Testing of originality Skills

\begin{tabular}{|c|c|c|c|c|c|c|}
\hline Administration & $\begin{array}{c}\text { No of } \\
\text { Students }\end{array}$ & Mean & $\begin{array}{l}\text { Standard } \\
\text { Deviation }\end{array}$ & $\begin{array}{c}\text { Degree } \\
\text { of } \\
\text { Freedom }\end{array}$ & $\begin{array}{c}\text { "t" } \\
\text { Value }\end{array}$ & Significance \\
\hline Pre & \multirow{2}{*}{25} & 10.1000 & 2.23375 & \multirow{2}{*}{29} & \multirow{2}{*}{22.592} & \multirow{2}{*}{$* *$} \\
\hline Post & & 23.3000 & 2.29166 & & & \\
\hline
\end{tabular}

Table 5 : shows that the mean scores gained by the students of the participants were higher on the post-testing of originality skills (23.1600) than those obtained on the pretesting (10.1000). "T" value is (22.592) which is significant at (0.05) level. These high gains of the students in the post-testing of originality skills were due to the training they had on the suggested E- program. The results of this 


\section{The effectiveness of using blogs on improving secondary school students`creative writing skills}

hypothesis provide an answer to the fourth sub question of the study as the results indicated that the suggested program was effective in improving originality skills of the group according to Blake's modified gain ratio (1.10) and the Etta square value (0.948).

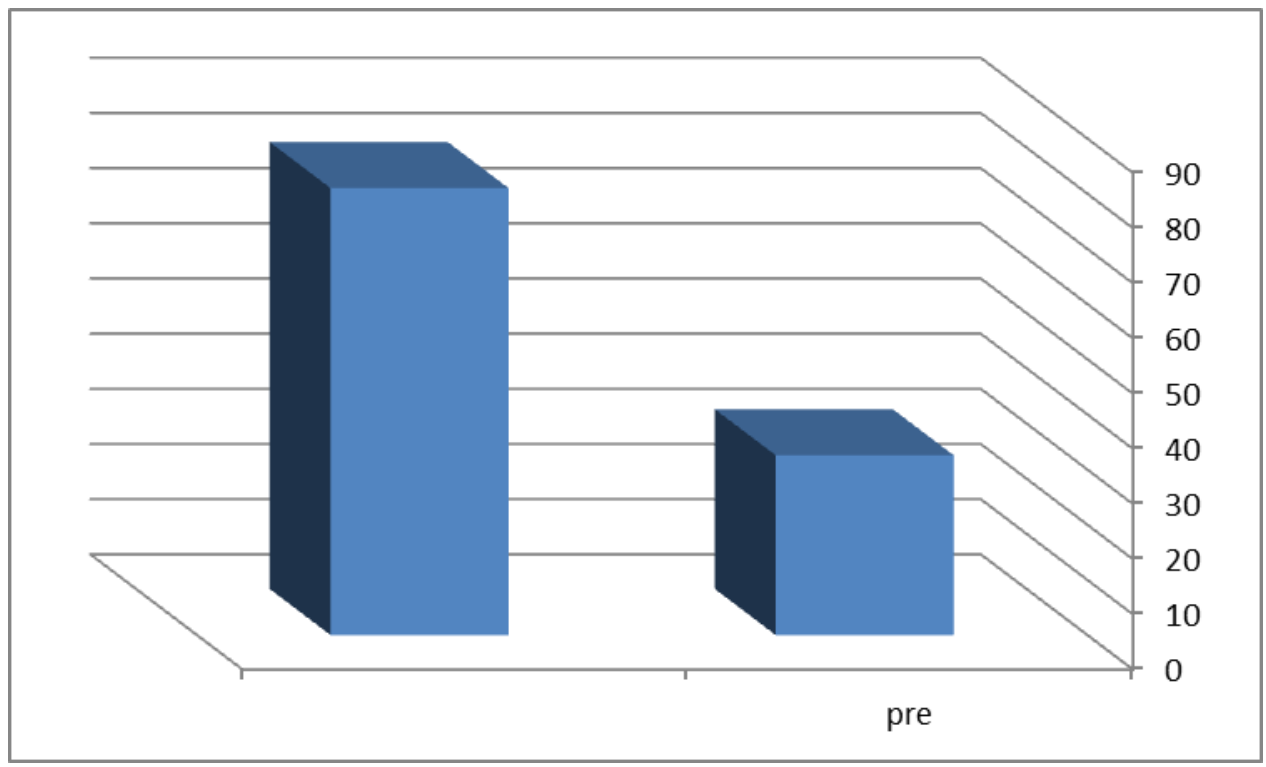

Figure 5. The Difference between pre and post testing of originality skills

\section{Discussion and conclusion}

The present study investigated the effectiveness of using a blog on improving first year secondary school students in the official language schools creative writing skills. Based on these results which were obtained on the posttest indicated that the participants achieved significant improvement in creative writing skills after being instructed through the blog. The use of blog helped in creating an appropriate and attractive environment for teaching creative writing skills. The Blog shifted the focus from teachers to students and encourages their engagement with the material. Through the online blog which used in the present study, 


\section{مجلة العلوم التربوية ـ كلية التربية بالغردقة - جامعة جنوب الوادى}

the traditional role of the students as passive reporters was changed, as they learn and practice creative writing skills meaningfully. Using blogs changed the environment of learning to be more attractive and meaningful to students. Through the blog students use a variety of tools or features (pictures, videos, online quizzes and webpages) to interact with online information. These tools may be in the form of navigation or cognitive tools. Using these tools which were different from the traditional teaching tools may pay their interest and attraction to learning. It also helped the students to practice more and different creative writing tasks.

One of the purposes of this study was that teaching creative writing skills would make students more successful and perform better in the target language skills. In each lesson, students wrote to achieve the objectives of the lesson. The most important advantages of the whole language approach were that it gave the students more time to communicate using English language. Another advantage of this approach was that the students were exposed to language which helped them to improve their skills generally and creative writing skills practically in the English language.

The supportive feedback which students received throughout the writing tasks helped them greatly to improve their writing, creative writing skills and gain self-confidence. This feedback started with sharing students' first and second draft with the rest of the class through the blog where the teacher and their peers write comments that help to improve the quality of the content and the organization of ideas. After that, students received another form of feedback through the use of agreed upon analytic rubrics that focused on the target areas of creative writing (fluency, elaboration, flexibility and originality). These rubrics help students to selfcorrect their writing texts. Moreover, this helps students to improve their creative writing skills and increase their self-confidence and motivation at the same time. While teaching the program several procedures were used based on blog. Those procedures gave students the opportunities to share responsibility in their learning. 


\section{The effectiveness of using blogs on improving secondary school students`creative writing skills}

That entitled a necessary change in the teacher's role. The teacher has become a guide, an organizer, and a facilitator, who does not impose his viewpoints on the students and who is ready to offer help when needed. The duration of the program lasted for seventy-two hours in one academic term (2020), six hours a week It also might have had its positive effect on the students performance. The researcher suggested that the longer the period spent in instruction, the better the chances that training was remain and be transferred to other situations.

Findings of the study are encouraging as they showed that there were statistically significant differences between the mean scores of the study sample on the pre-posttest of creative writing skills test in favor of the post applications. This indicates that the creative writing skills which were included in the study have been improved. The students' scores on the pre-test were unsatisfactory. Before implementing the study, they had not got any training in the previously specified creative writing skills. Therefore, through this study, students had an opportunity to practice creative writing skills. As a result, they became able to get higher scores on the posttest.

The present study gave a useful evidence about the effectiveness of a blog on improving the first-year secondary school students`creative writing skills . Definitely, this study was intended to be distinguished from other studies by using online blog to improve participants`creative writing skills. Additionally, although the program was effective in developing students` creative writing skills, but it could be more effective if the following points were taken into consideration:

- The students need more training for the using of online blogs in isolation before implementing the program.

- More focus and training needed for writing mechanics from the beginning of the program. 


\section{مجلة العلوم التربوية ـ كلية التربية بالغردقة ـ جامعة جنوب الوادى}

- More time should be allotted to oral activities to give the students the opportunity to think and prepare their answers which may lead to increase the time of teaching the lessons in the program.

\section{Definition of terms}

\section{Blog:}

According to Mortensen \& Walker (2002) blogs are frequently updated websites, usually personal, with commentary and links. Drezner \& Farrell (2004) express a blog as a web page with minimal to no external editing, providing online commentary, periodically updated and presented in reverse chronological order, with hyperlinks to other online sources. The study adopts the following definition due to its nature, Mckenna \& Pole (2004) define blogs as web pages that are regularly updated, operated by one person or a small group of people and developed for little to no cost. Individual entries or posts are chronologically updated like a diary with the most recent posts viewed first.

\section{Creative writing}

Warut ( 2002) defines creative writing as a way that a person writes his/her work to be more creative and thoughtful. The aspects of creative writing include imagination, experience and fantastic designing. Using brainstorm is the most important activity. Ramet (2004) states that the term creative writing has been defined as having the power to create an imaginative and original literary production or composition. The researcher adopted the last definition for the present study. 


\section{The effectiveness of using blogs on improving secondary school students`creative writing skills}

\section{References}

Reddy, C. \& Waghid, Y. (2004). Environment as Community. SA Journal of Higher Education, Vol-18 (1) Tamopolsky (2005). Writing English as a Foreign Language: A report from Ukraine. Journal of Second Language Writing, 9(3), 209-226

Khalaf Ibnian, S. S. (2011). Brainstorming and essay writing in EFL class, faculty of arts and sciences. Middle East University, 269.

Ahmed, R. A. I. (2011). The effect of using journal writing on developing some creative writing skills for the secondary stage students.

Ali, M. (2009). The Effect of a Training Program Based on some Creative Writing

Strategies on Developing the Creative Writing Skills of First Year Secondary. Master`s Dissertation, Faculty of Education, Minia University

Tarnopolsky, O. (2000). Writing English as a foreign language: A report from

Ukraine. Journal of Second Language Writing, 9(3), 209-226.

Stillar, S. (2013). Raising critical consciousness via creative writing in the EFL

classroom. TESOL Journal, 4(1), 164-174.

Hennings, D. G. (1997). Communication in action: Teaching literature-based

language arts. Houghton Mifflin Company, 181 Ballardvale Street, Wilmington, MA 01887. 
مجلة العلوم التربوية ـ كلية التربية بالغردقة - جامعة جنوب الوادى

El-Behery, A. (2013), The Effect of Using Collaborative Online Learning Strategy on Developing some creative Writing Skills of EFL Collage Students. Master's Dissertation, Faculty of Education, Menoufia University

Lee, L. (2010). Fostering reflective writing and interactive exchange through blogging in an advanced language course. $\operatorname{ReCALL}, 22$ (2), 212-227

Reddy, C. \& Waghid, Y. (2004). Environment as Community. SA Journal of Higher Education, Vol-18

Zhang, D. (2009). The Application of Blog in English Writing. Journal of Cambridge Studies, 4(1)

Benson, J. \& Reyman, J. (2009). Learning to Write Publicly: Promises and Pitfalls of Using Weblogs in the Composition Classroom. Retrieved from

http://www.john-benson.net/blogstudy/ 